Proc. Indian Acad. Sci., Vol. 81 B, No. 6, 1975, pp. 249-253

\title{
Effects of temperature-salinity combinations on the digestion rates of Gambusia affinis
}

\author{
Katre Shakuntala \\ Department of Zoology, Bangalore University, Bangalore 560001 \\ MS received 15 January 1975; after revision 12 April 1975
}

\begin{abstract}

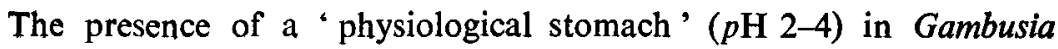
affinis is proposed based on measurements of $p \mathrm{H}$ in the gut and food intake of fish starved for 5 days, as a function of temperature and salinity of the environment. Digestion was fastest in $3 \%$ salinity at $30^{\circ} \mathrm{C}$ and slowest at $20^{\circ} \mathrm{C}$ in freshwater.
\end{abstract}

\section{INTRODUCTION}

RICKER ${ }^{1}$ recognized that digestion rates have an important bearing on fish production. A definite influence of temperature on the digestion rate has been demonstrated in several fishes ${ }^{2-7}$. But the effects of salinity changes on digestion rate in fishes have not been demonstrated so far. The cffects of different temperature-salinity combinations on the digestion rate of the mosquito fish Gambusia affinis have been described in this paper.

\section{Materials AND METHODS}

Large female Gambusia affinis were collected from the Bellandur fish farm (near Bangalore) and starved for a period of 5 days at the chosen tomperature $\left(20^{\circ}, 25^{\circ}\right.$ and $\left.30^{\circ} \mathrm{C}\right)$ and salinity combinations (freshwater, 3 and $7 \%$ S) to elicit a state of hunger in them. On the sixth day, the fish were fed a known amount of Oligochaete worms, Tubifex tubifex, over a period of 30 minutes. At the end of the 30 minute period, the quantity of food consumed by each fish during this period was recorded as $\mathrm{mg}$ Tubifex worms consumed/g body weight of the fish/day.

At intervals of 30 minutes, representative test individuals at each tcmpcrature-salinity combination were killed following the 'serial slaughter' procedure of Windell ${ }^{8}$. The alimentary canal of the fish was dissected to note the presence of food in the 'stomach' and intestine, changes in $p \mathrm{H}$ 
values and gut evacuation time. The duration from the time of feeding till the 'stomach' was cleared of food, was taken as the total digestion period and digestion rate was expressed as $\mathrm{mg}$ food digested $/ \mathrm{hr}$.

\section{Results AND Discussion}

\section{Effects of 5 days starvation on 'satiation'}

Since the individuals at the respective temperature-salinity levels were starved for 5 days, at the time of feeding on the sixth day, the stomachs of all the fish should have been cleared of food, and when the individuals were given an opportunity to feed on excess amount of food, all the fish should have consumed to their respective satiation. However, there were appreciable differences in the food intake among the test individuals ind1cating that temperature and salinity considerably altered the satiation level of these fish (table 1). At $25^{\circ} \mathrm{C}$, feeding rate increased with increase in salinity $\left(48.0\right.$ to $120.3 \mathrm{mg} / \mathrm{g} /$ day); a similar trend was seen at $20^{\circ} \mathrm{C}(20 \cdot 5$ to $48.0 \mathrm{mg} / \mathrm{g} /$ day). However, at $30^{\circ} \mathrm{C}$, the fish exhibited a decrease in the feeding rate as the salinity increased. Previously, it was noted that when reared with unrestricted amount of Tubifex tubifex, the food intake of Gambusia affinis at $30^{\circ} \mathrm{C}$ in $7 \% \mathrm{~S}$ was the maximum compared to other salinity levels ${ }^{9}$. But in the present experiment, the individuals consumed only $8.4 \%$ of their body weight in $7 \%$ S at $30^{\circ} \mathrm{C}$. This may be due to prestarvation, which rapidly depletes the energy store of fish at higher tempeture ${ }^{10}$. Hence, the test fish consumed only $9 \cdot 2,8.9$ or $8.4 \%$ of their body weight in freshwater, 3 or $7 \%$ salinity at $30^{\circ} \mathrm{C}$. This indicates that at higher temperatures, the satiation level was lowered probably due to the lowering of energy store. The overall low rate of feeding even after starvation and complete 'stomach' clearance indicates that the 'stomach' clearance alone does not restore the 'appetite' to capacity and that other extrinsic factors like temperature and salinity also influence the satiation level.

\section{$\mathrm{pH}$ changes and evacuation of the gut}

The changes in $\mathrm{pH}$ range in 'stomach' as well as the intestine of Gambusia affinis in relation to time have been presented in figures 1-3 for fish reared at $30^{\circ}, 25^{\circ}$ and $20^{\circ} \mathrm{C}$, respectively. In G. affinis (Poeciliidae) and in many Cyprinodontidae, a histologically and anatomically defined 'stomach' is known to be lacking and it is reported that a short oesophagus leads directly into the intestine ${ }^{11-13}$. During the present study however, it was noticed that in G. affinis, the anterior region of the intestine had a distended region where not only did the food remain for a long time (4 to $6 \mathrm{hr}$; figures 1-3), but also underwent digestion, as could be seen by the distinte- 

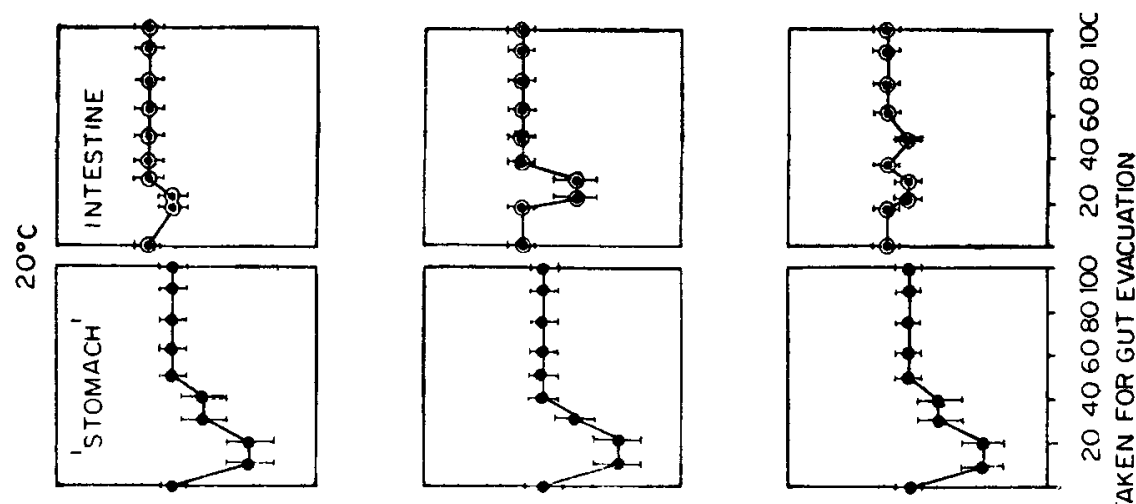

0

กิ

0

ż :

只
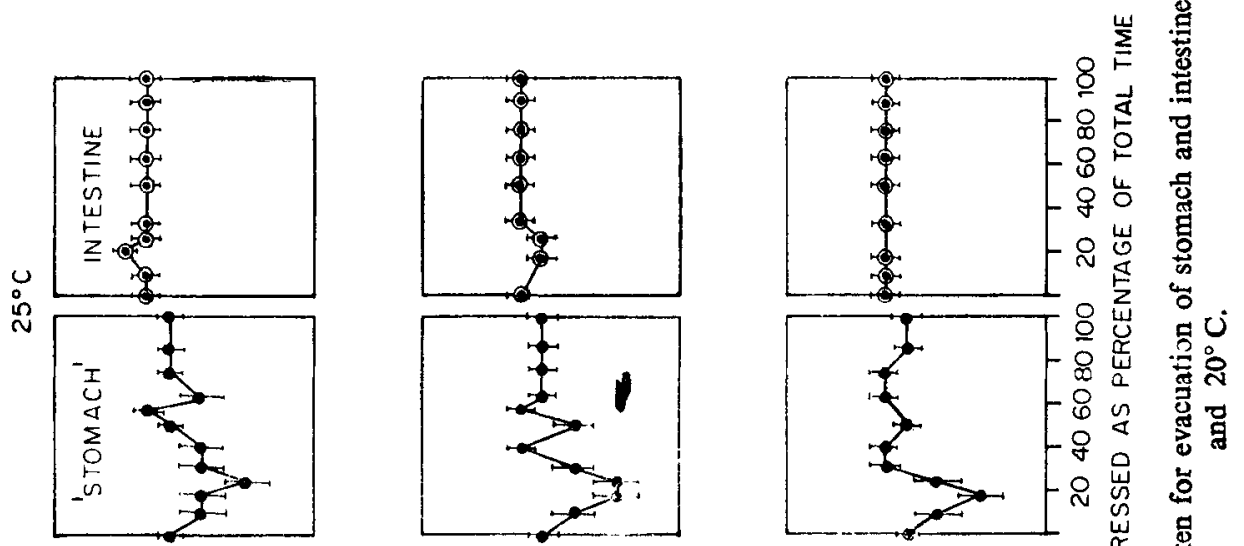

8

:

爻

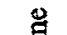

넹

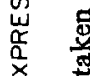

急
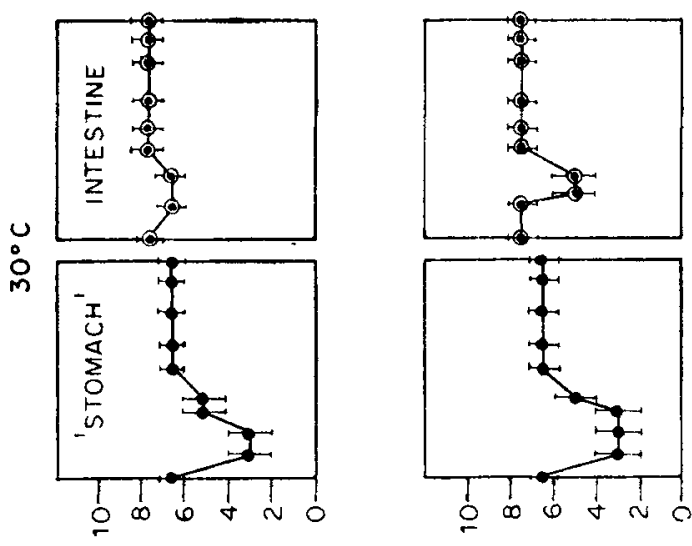

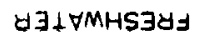

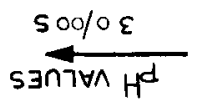

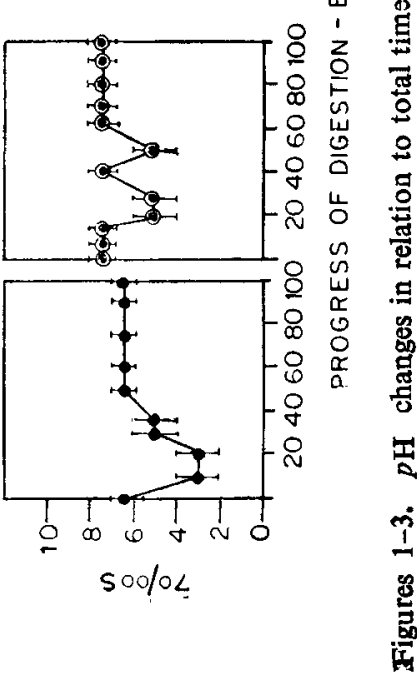


Table 1. Effects of temperature-salinity combinations on the duration and rates of digestion in female Gambusia affinis fed after a period of 5 days of starvation. Data given in parentheses represents the range.

\begin{tabular}{|c|c|c|c|c|c|c|}
\hline \multirow{2}{*}{$\begin{array}{l}\text { Tempe- } \\
\text { rature } \\
{ }^{\circ} \mathrm{C}\end{array}$} & \multirow[t]{2}{*}{$\begin{array}{c}\text { Salinity } \\
(\% 0)\end{array}$} & \multirow{2}{*}{$\begin{array}{l}\text { Average live } \\
\text { body weight } \\
\text { (mg) }\end{array}$} & \multirow[t]{2}{*}{$\begin{array}{l}\text { Feeding rate } \\
\text { (mg/g live fish) }\end{array}$} & \multicolumn{2}{|c|}{$\begin{array}{l}\text { Time required for full } \\
\text { evacuation of }\end{array}$} & \multirow{2}{*}{$\begin{array}{l}\text { 'Gastric' } \\
\text { digestion } \\
\text { rate }(\mathrm{mg} / \mathrm{hr})\end{array}$} \\
\hline & & & & $\begin{array}{l}\text { 'stomach' } \\
(\mathrm{hr})\end{array}$ & $\begin{array}{l}\text { Intestine } \\
\text { (hr) }\end{array}$ & \\
\hline \multirow{3}{*}{30} & Freshwater & 919 上. 68.5 & $92 \cdot 1 \pm 1 \cdot 18$ & $\begin{array}{c}7 \\
(6 \text { to } 8)\end{array}$ & $\begin{array}{c}11 \\
(10 \text { to } 12)\end{array}$ & $13 \cdot 19 \pm 0 \cdot 23$ \\
\hline & 3 & $927 \pm 55 \cdot 6$ & $89 \cdot 0 \pm 1 \cdot 12$ & $\begin{array}{c}5 \\
(4 \text { to } 6)\end{array}$ & $\stackrel{9}{(8 \text { to } 10)}$ & $17 \cdot 80 \pm 0 \cdot 82$ \\
\hline & 7 & $999 \pm 50 \cdot 3$ & $83 \cdot 9 \pm 0 \cdot 98$ & $\begin{array}{c}5 \\
(4 \text { to } 6)\end{array}$ & $\begin{array}{c}11 \\
(10 \text { to } 12)\end{array}$ & $16 \cdot 78 \pm 0 \cdot 84$ \\
\hline \multirow{3}{*}{25} & Freshwater & $815 \pm 67 \cdot 3$ & $82 \cdot 7 \pm 1 \cdot 23$ & \multirow{2}{*}{$\begin{array}{c}9 \\
(8 \text { to } 10) \\
9 \\
(8 \text { to } 10)\end{array}$} & \multirow{2}{*}{$\begin{array}{c}13 \\
(12 \text { to } 14) \\
13 \\
(12 \text { to } 14)\end{array}$} & $9 \cdot 19 \pm 0 \cdot 17$ \\
\hline & 3 & $755 \pm 43 \cdot 3$ & $108 \cdot 9 \pm 2 \cdot 08$ & & & $12 \cdot 10 \pm 0 \quad 56$ \\
\hline & 7 & $706 \pm 39 \cdot 0$ & $120 \cdot 3 \pm 1 \cdot 95$ & $\begin{array}{c}7 \\
(6 \text { to } 8)\end{array}$ & $\begin{array}{c}13 \\
\text { (12 to } 13)\end{array}$ & $17 \cdot 19 \pm 0 \cdot 24$ \\
\hline \multirow{3}{*}{20} & Freshwater & $812 \pm 95 \cdot 4$ & $20 \cdot 5 \pm 0 \cdot 79$ & $\begin{array}{c}15 \\
(14 \text { to } 16)\end{array}$ & Over 18 & $1 \cdot 37 \pm 0 \cdot 09$ \\
\hline & 3 & $1338 \pm 216 \cdot 5$ & $20 \cdot 9 \pm 0 \cdot 98$ & $\begin{array}{c}11 \\
\text { (10 to 12) }\end{array}$ & Over 16 & $1.90 \pm 0.08$ \\
\hline & 7 & $1248 \pm 342 \cdot 5$ & $48 \cdot 0 \pm 1 \cdot 25$ & $\stackrel{9}{(8 \text { to } 10)}$ & Over 16 & $5.33 \pm 0.98$ \\
\hline
\end{tabular}

gration of intact food into a fluid like chyme. From figures 1-3 it is clear that only in this region the $p \mathrm{H}$ reduced to the acidic range of 2 to 4 when the food was present and digested. Before and after these time limits the $p \mathrm{H}$ of this region was almost neutral (6 to 7), but always lower than that observed in the rest of the posterior intestine ( 7 to 8$)$. This suggests that acid was produced in this region of the gut. The production of acidic condition and the breaking down of the food material definitely indicates the secretion of pepsin ${ }^{12}$. Therefore, it is evident from the present study that if not a histological or anatomical one, a physiological equivalent of a 'stomach' is present in G. affinis.

In the intestine, the $p \mathrm{H}$ remained mostly in the alkaline range (7 to 9). The slight decreases in $p \mathrm{H}$ of the intestine from the alkaline range to 6-7 $\left(20^{\circ} \mathrm{C}\right.$, freshwater and $\left.7 \% \mathrm{~S}\right)$ or $4-6\left(20^{\circ} \mathrm{C}, 3 \% \mathrm{~S}\right.$ and $\left.30^{\circ} \cdot \mathrm{C}, 3 \% \mathrm{~S}\right)$ might have been caused by the arrival of digested food along with some acidic content of the 'stomach' just at the time of observation ${ }^{8}$. On an average, digestion occurred in the stomach within 10 to $30 \%$ of the total 
time taken for complete gut evacuation, irrespective of the temperaturelevels (figures 1-3). However, the total time taken for complete evacuation of the gut depended on temperature $\left(8\right.$ to $12 \mathrm{hr}$ at $30^{\circ} \mathrm{C}, 12$ to $14 \mathrm{hr}$ at $25^{\circ} \mathrm{C}$ and $16 \mathrm{hr}$ or more at $20^{\circ} \mathrm{C}$ ).

\section{Digestion rate}

Irrespective of the salinity levels, digestion rate averaged to $15.92 \pm$ $2 \cdot 42,12 \cdot 82 \pm 4 \cdot 10$ and $2.53 \pm 2.91 \mathrm{mg} / \mathrm{hr}$ at $30^{\circ}, 25^{\circ}$ and $20^{\circ} \mathrm{C}$ respectively. On applying Student ' $t$ ' test, the differences in the three values were found to be significant at $5 \%$ level. This indicates that digestion rate depended on temperature. Smit ${ }^{5}$ reported that in the fish Ictalurus nebulosus the output of gastric juice increased with increasing temperature (see also Brett and $\mathrm{Higgs}^{8}$ ). In the present study, the increased digestion rates obtained in the higher temperature series may be due to similar increases in the rates of secretion.

Considering the different salinity levels alone, from the present experiment it becomes evident that excepting the value at $30^{\circ} \mathrm{C} 3 \% \mathrm{~S}$, the digestion rates increased with increase in salinity at all temperatures. For instance it increased from $13.2 \mathrm{mg} / \mathrm{h}$ in freshwater to $170 \mathrm{mg} / \mathrm{h}$ in $7 \% \mathrm{~S}$ at $30^{\circ} \mathrm{C}$; similar increases of 9.2 to $17.2 \mathrm{mg} / \mathrm{h}$ and 1.4 to $5.3 \mathrm{mg} / \mathrm{h}$, from freshwater to $7 \% \mathrm{~S}$ were exhibited at $25^{\circ}$ and $20^{\circ} \mathrm{C}$ respectively. Gambusia affinis fed on Tubifex tubifex at $25^{\circ} \mathrm{C}$ and freshwater digested at the rate of $9.2 \mathrm{mg} / \mathrm{g} / \mathrm{h}$. This is rather high compared to that of the bluegill sunfish (Lepomis macrochirus) fed on the mayfly naid $\left(0.02 \mathrm{mg} / \mathrm{g} / \mathrm{h}\right.$, Windell $\left.{ }^{8}\right)$,

\section{REFERENCES}

1. Ricker, W. E., Ecol. Monogr. 16 373-391 (1946).

2. Markus, H. C., Trans. Am. Fish. Soc. 62 202-210 (1933).

3. Molnar, G. Y. and Tölg, I., J. Fish. Res. Bd. Canada 19 1005-1012 (1962).

4. Fabian, G. Y., Molnar, G. Y. and Tölg, I., Acta Biol. Acad. Sci., Hung. 14 123-129 (1963).

5. Sinit, H., Comp. Biochem. Physiol. 21 125-132 (1967).

6. Brett, J. R. and Higgs, D. A., J. Fish. Res. Bd. Canada 27 1767-1779 (1970).

7. Tyler, A. V., J. Fish. Res. Bd. Canada 27 1177-1189 (1970).

8. Windell, J. T., in Tie Biological Basis of Freshwater Fish Production. Blackwell Scientific Publications, Oxford (1967).

9. Katro, S., Exophysiological Studies on growth and reproduction of some thermoconformers. Ph.D. Thesis, Bangalore University (1973)

10. Savitz, J., J. Fish. Res. Bd. Canada 26 1813-1821 (1969).

11. Schazht, H., Ube: der Vorderarm der Cyprinodonten. Z. Mikroskop. Anat. Forsch. 26 534-546 (1931).

12. Barrington, E. J. W., The Physiology of Fishes. Vol. 1, 109-161, Academic Press, New York (1957).

13. Bullock, W. L., Acta Zool. (Stockholm) 48 1-17 (1967).

14. Windell, J. T., Invest. Indiana Lakes, Streams, 1, 185-214 (1966) 